\title{
Accumulation of Copper and Zinc Metals from Water in Anabus testudineus Fish Species in Bangladesh
}

\author{
Nehreen Majed ${ }^{1, *}$ (D) Md. Kawser Alam, Md. Isreq Hossen Real², Mohidus Samad \\ Khan $^{3}$
}

${ }^{1}$ Department of Civil Engineering, University of Asia Pacific, 74/A, Green Road, Dhaka-1205, Bangladesh.

${ }^{2}$ Department of Civil and Environmental Engineering, Manhattan College, Newyork, NY, USA.

${ }^{3}$ Department of Chemical Engineering, Bangladesh University of Engineering \& Technology, Dhaka-1000, Bangladesh.

\section{Article History \\ Received May 28, 2019 \\ Accepted Jul 16, 2019}

First Online Aug 21, 2019

\section{Corresponding Author}

Tel.: +8801819206394

E-mail: nehreen23@gmail.com

\section{Keywords}

Heavy metal

Metal uptake

Fish muscle

Bio-concentration

\begin{abstract}
Excessive concentrations of heavy metals impair ecosystems as some of those cause potential bioaccumulation in living beings. Fishes are the major inhabitants in water bodies which can be highly affected by these toxic pollutants. This study investigated the uptake trends of the metals copper and zinc from water in Anabas testudineous, a common fish species in Bangladesh. The accumulation of heavy metals was quantified in the species during time bound batch experiments with metal dosing. Metal uptake trend in fish muscles revealed that, uptake of $\mathrm{Zn}$ in fish occurred at an elevated level ( 7-8 times) than that of $\mathrm{Cu}$. With uptake of metals in fish muscles from water, $\mathrm{Cu}$ concentration in the water decreased concomitantly whereas the concentration of $\mathrm{Zn}$ did not change noticeably. Correlation analysis indicated significant changes in internal dynamics among water quality parameters between control and experimental tanks. Bio-concentration profile for the metals revealed very high levels for $\mathrm{Zn}$ (5-10 times) than those for $\mathrm{Cu}$ evidently due to higher amount of uptake of $\mathrm{Zn}$. To summarize, dynamics of heavy metal metabolism in the fish species and their respective correlation with the water quality parameters may vary for different heavy metals and for different fish species as well.
\end{abstract}

\section{Introduction}

In recent years, there has been an increasing ecological and global public health concern associated with environmental contamination by the heavy metals (Bradl, 2005) due to their bioavailability, nondegradability, long half-life, bioaccumulation and biomagnification properties. Fishes are the most widely distributed organisms living in marine environments and are well-known for their ability to concentrate heavy metals in their muscles. Additionally, fish is an important indicator for the accumulation of pollutant, especially, heavy metals in the food chain as well as a bio-indicator of aquatic ecosystem (Pan \& Wang, 2012; Vieira, Morais, Ramos, Delerue-Matos, \& Oliveira, 2011).
In general, most of the heavy metals are known for their toxicity and lethal effects but trace metals like $\mathrm{Cu}$ and $\mathrm{Zn}$ are essential for growth of organisms (Shukla, Dhankhar, Prakash, \& Sastry, 2007). However, trace metals are persistent, non-biodegradable and can be lethal for aquatic organisms if present beyond a threshold level (Chandurvelan, Marsden, Glover, \& Gaw, 2015). High exposure of these metals can induce sub lethal effect at molecular and cellular levels of organisms (Tsangaris, Kormas, Strogyloudi, Hatzianestis, \& Neofitou, 2010) and affect the survival capacity by reducing the susceptibility rate of organisms to disease (De Montaudouin et al., 2010). However, uptake rates have been shown to vary for organisms when subject to nonessential and trace metal exposure (Amiard, Amiard- 
Triquet, Berthet, \& Metayer, 1987). Copper is essential for enzymes and important for hemoglobin synthesis (Rahman, Molla, Saha, \& Rahman, 2012). However, high intake of $\mathrm{Cu}$ can create adverse problems (Rahman et al., 2012). Similarly, Zinc is a potential toxicant to fish and get accumulated in the fatty tissues of aquatic organisms due to high exposure causing disturbances of acid-base, ionoregulation and disruption of gill tissue in fishes (Hogstrand, Wilson, Polgar, \& Wood, 1994). Moreover, $\mathrm{Zn}$ accumulation in high concentration is also reported to cause Alzheimer's disease (Murugan, Karuppasamy, \& Poongodi, 2008).

Bangladesh is well known for wide river networks throughout the country. These inter-connected rivers are now highly polluted with different chemical residues that are being spontaneously released from various industries. Emission of $\mathrm{Zn}$ occurs from domestic construction and car related sources (Mohiuddin, Otomo, Ogawa \& Shikazono, 2012), whereas Cu is mostly entering through sewage discharge into the rivers (Sarkar et al., 2015). Furthermore, there have been several studies reporting enrichment of trace metals in water, sediment, and fish species in various rivers (Ahmad, Islam, Rahman, Haque, \& Islam, 2010; Ahmed et al., 2015; Rahman et al., 2012; Begum et al., 2013; Sarkar et al., 2015; Islam, Ahmed, Raknuzzaman, Habibullah-Al-Mamun, \& Islam, 2015; Mohiuddin, Ogawa, Zakir, Otomo, \& Shikazono, 2011). Specific findings on trend of metal uptake by fish species when exposed to dissolved metals in the water could elucidate on the susceptibility rate of fish species. This finding could eventually be used as an environmental indicator to validate the suitability of consumption of specific fish/other aquatic lives from the river and design strategies toward ecological protection for public health. Numerous studies (Shukla et al., 2007; Amiard et al., 1987; Murugan et al., 2008; DeForest, Brix, \& Adams, 2007; Vinodhini \& Narayanan 2008; Ambreen, Javed, \& Batool, 2015) have investigated on uptake of different heavy metals by different fish species at exposure of different metal mixtures in laboratory condition. However, no significant studies have been found to date in Bangladesh to understand the metal uptake rate by any local fish species under laboratory setup.

Bioaccumulation potential can be expressed using Bio concentration factor (BCF) to understand chemical concentrations in organism tissue relative to chemical exposure concentration (DeForest et al., 2007). Bio accumulation factor (BAF) differs from BCF in that the chemical concentration in the aquatic organism results from all possible routes of exposure and mainly calculated based on field data (Gobas \& Morrison, 2000). Previous studies (Cui, Ge, Zhu, Yang, \& Wang, 2015; Dwivadi, Tiwari, \& Mayank, 2015; Falusi \& Olanipekun, 2007; Orata \& Birgen, 2016) measured BCF and BAF to measure the concentration of metals in fish species to understand exposure of metals from the sediment and water.
The primary objective of this study was to investigate the competitive uptake trends and synergistic effects of copper ( $\mathrm{Cu}$ ) and zinc ( $\mathrm{Zn}$ ) when fish are exposed to these heavy metals in a controlled environment. Anabas testudineus (Climibing perch) locally known as "Koi", is a common freshwater species in Bangladesh and also widely distributed in India, Bangladesh, Pakistan and other south eastern countries (Sarma et al., 2010; Bhaskar, Pyne, \& Ray, 2015). Climbing perch is omnivorous in food habit and very well known for its breathing ability in air. The species is categorized into labyrinthine fish group as generally comes to the surface to obtain air (Hughes \& Singh, 1970). Being a common edible fish and considered as good dietary item for sick person, it has been selected as subject of the present study. Furthermore, other physical and chemical properties of water influencing the uptake trends or influenced by the metal uptake dynamics were assessed as well to be further studied by Pearson correlation and linear regression analysis. Finally, BCF values were evaluated and compared for both of the metals and their trends were assessed during the experimental duration.

\section{Materials and Methods}

The main route of metal uptake for fish is direct contamination from water (Bouquegnean, NoelLambot, \& Disteche, 1979). Assuming little contribution of other routes of metal uptake for fish, batch experiments in laboratory scale were carried out considering water as the key route of metal accumulation in fish. Anabas testudineus (Climbing perch) was selected for the experiment for their availability and survival reputation in severely polluted aquatic environment.

\section{Batch Testing Setup}

Fish samples of Anabas testudineus weighted 29.8 $\pm 2.58 \mathrm{~g}$ were obtained from local fish market of Dhaka, where fresh local fishes are brought every day to sell from nearby water sources. Collected fish samples were then transported in laboratory with proper oxygenation and kept at room temperature and pressure so that they could become adjusted to the lab environment. Two rectangular tanks made of concrete; capacity 2000 liter/each were used in the first trial to conduct the experiment. One tank was used as the control and the other as the experimental. Each tank was filled with 300 liters of tap water. The physical and chemical properties of tap water were analyzed. Twenty-five samples of fish were added in each tank, kept in open air condition and were fed twice daily with standard fish feed. A sub-lethal concentration of $5 \mathrm{ppm}$ of $\mathrm{Cu}$ and $\mathrm{Zn}$ was initially dosed based on the literature (Ambreen et al., 2015; Vinodhini and Narayanan, 2008) for an acclimation period of 15 days. With such combined concentrations, the fishes in the experimental tank could not survive more than 7 
days. Accordingly, concentration of metal toxicant was reduced to $1 \mathrm{ppm}$ and the fishes were added to the cylindrical tanks made of PVC with capacities of 1250 liter/each tank. The volume of tap water in cylindrical PVC tank water was same as previous. Zinc sulfate $\left(\mathrm{ZnSO}_{4}\right)$ and copper sulfate $\left(\mathrm{CuSO}_{4}\right)$ salts were added to provide $\mathrm{Zn}$ and $\mathrm{Cu}$ of $1 \mathrm{ppm}$ concentration in the experimental tank. In all the tanks, fishes survived and their physical strength and appearance seemed acceptable after dosing. After 15 days of acclimation period, regular feeding was stopped and fish were collected using the fish net for sampling. Figure 1 shows the photographs of experimental tank and the fish species collected in fish net respectively. The control tank contained the same amount of fish species and the tank was not dosed with the metal solutions.

\section{Sampling and Analysis of Water Quality Parameters}

After dosing, sampling of both water and fish species for a 15 days' span from both experimental and control tank were carried out for every two days' interval until $9^{\text {th }}$ day and then for every three days' interval until $15^{\text {th }}$ day. Different physico-chemical parameters, such as: $\mathrm{pH}$, temperature, electric conductivity (EC), total dissolved solids (TDS), dissolved oxygen (DO), alkalinity, hardness, ammonia nitrogen (A. Nitrogen), chloride, and sulfate of water samples were analyzed using standard analytical procedure (Clesceri, Greenbaerg, \& Eaton, 1998). Water samples and fish samples were analyzed for the $\mathrm{Cu}$ and $\mathrm{Zn}$ metals and the procedure is detailed below.

\section{Heavy Metal Analysis}

Total $10 \mathrm{~g}$ of fish sample including parts from head, liver, gills, bones, and scales were taken in a digestion flask. $10 \mathrm{~mL}$ of concentrated nitric acid (65\%) and $8 \mathrm{~mL}$ of concentrated sulfuric acid (99\%) were added to the flask. The flask was then heated under reflux. When red vapors started to emanate, $15 \mathrm{~mL} 30 \% \mathrm{H}_{2} \mathrm{O}_{2}$ was added by turns ( $5 \mathrm{~mL}$ in each turn) until the flask got clear. When no more vapors seemed to form, digestion was said to be complete. The flask was then removed from the heating chamber and allowed to cool. After the flask was cooled, the digested sample was filtered. $2.5 \mathrm{~mL}$ of the filtrate was taken and $22.5 \mathrm{~mL}$ of distilled water was added to create a $10 \mathrm{x}$ diluted sample and $\mathrm{pH}$ was controlled from 4.0 to 5.0. Copper and Zinc were then quantified from the solution by $\mathrm{HACH} 4000$ Spectrophotometer, using $\mathrm{HACH}$ programs 1700 and 3850 respectively.

\section{Statistical Analysis}

Statistical analyses were performed using the SPSS 20 software (IBM Inc., USA). Pearson's correlation and linear regression analysis was carried out to determine correlation between different parameters and understand the trend of different parameters both in control and experimental conditions. Statistical significance was set to a level of $5 \%(p<0.05)$.

\section{Calculation of Bioconcentration Factor}

The bioconcentration factor relating the concentration of heavy metal in water and the fish can be calculated using the following formula by (Dwivedi et al., 2015; Sikdar \& Kundu, 2018).

The bioconcentration factor, $B C F=C_{f} / C_{w}$, Where, $C_{f}$ is the level of heavy metal in fish in milligram per kilogram and $C_{w}$ is the heavy metal concentration in water.

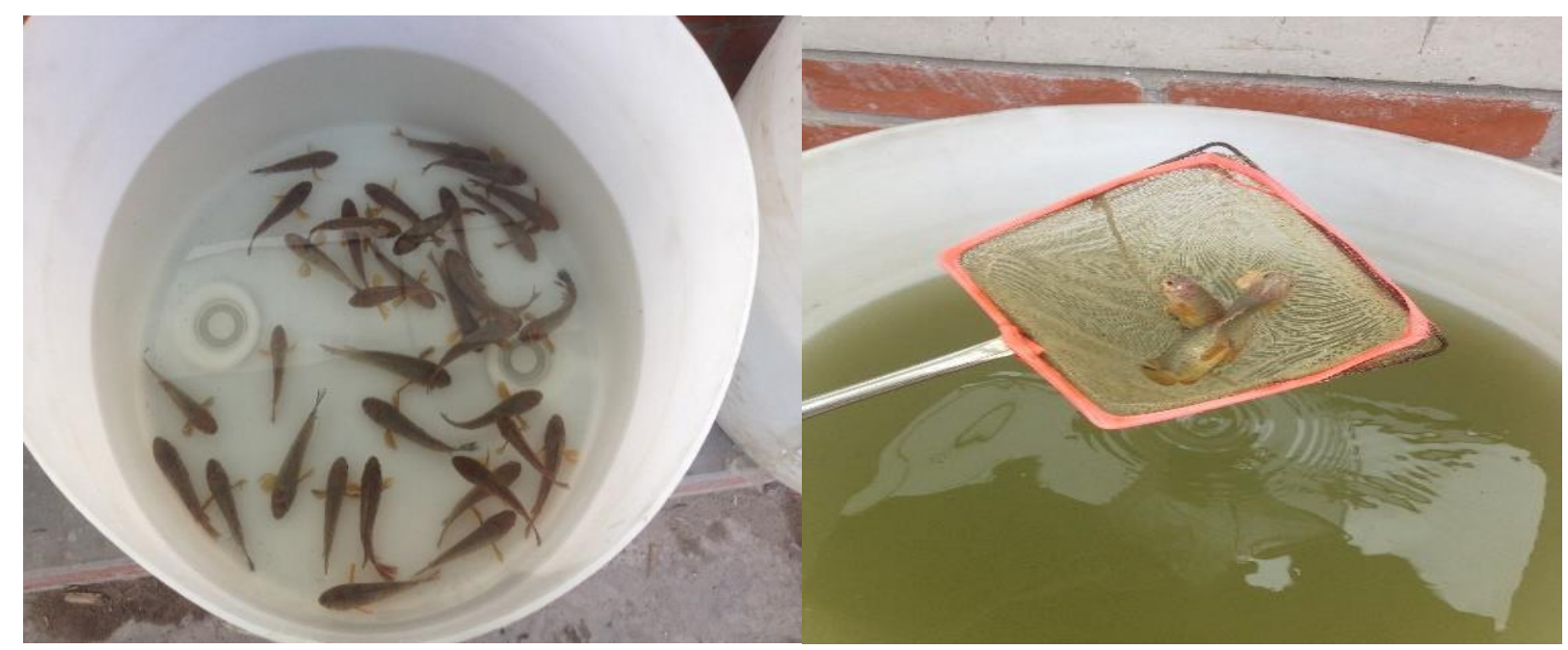

Figure 1. Fish samples in PVC tanks (left) and Fish samples collected in fish net (right). 


\section{Results and Discussion}

Trends of Water Quality Parameters between Control and Experimental Tanks

Different water quality parameters were measured in the control and experimental tanks to realize the impact of sub-lethal metal doses in the experimental tank. Previously, different water quality parameters were measured by other studies (Vinodhini \& Narayanan, 2008; Yılmaz, Turan, \& Toker, 2010) to observe the difference between control and experimental tanks after dosing with toxic solution in experimental fish groups. The water quality parameters on which major impact was observed in the current study were electrical conductivity, ammonia nitrogen, chloride, dissolved oxygen and sulfate. Figures 2a-e, show the trends of the concentration levels that were measured in the control and experimental tanks for dissolved oxygen, chloride, electrical conductivity, ammonia-nitrogen and sulfate respectively during heavy metal dosing period.

It can be noticed from figure that in general, introduction of sub-lethal metal solution in experimental tank causes general increment in the levels of the water quality parameters. Among these, the trends for sulfate and chloride were found to be significant $(P<0.05)$ in the experimental tank. Due to the presence of salts in sub-lethal doses of metal solutions, the sulfate and chloride concentrations exhibited significant positive trends in the experimental tank and eventually the electrical conductivity of water increased. Meanwhile, incremental trend is observed for concentration levels of ammonia-nitrogen in the experimental tank in contrast to a descending trend which is observed in the control tank (Figure. 2). A progressing trend of concentration of ammonianitrogen in experimental tank is possibly the result of increase of nitrogen excretion due to the change in metabolites of fishes by heavy metal solution. It should be noted that previous studies (Boudjema, Meknachi, Kourdali, Bounakous, \& Badis, 2016; Cheung \& Cheung, 1995) found similar observation for mussels while exposed to high metal concentration in the laboratory setup. From figure 2, dissolved oxygen shows increasing trends of concentrations in control and experimental tank with days. But oxygen concentration levels are observed to be comparatively higher in the experimental tank. One previous study by Vinodhini and Narayanan (2008) also observed high level of oxygen in the experimental tank with fishes and reported the reason as alteration of respiratory function of fishes due to the effect of heavy metals. To conclude, metal solutions evidently resulted to alteration in the water quality in the experimental tank which eventually lead to the physical changes in fishes.
Trends of Heavy Metal Concentration Levels in fish Muscles and Water

Figure 3 shows the bioaccumulation of copper and zinc from metal-dosed water of the experimental tank into the fish muscles. The graphical values represent the differences between the heavy metal concentrations in fish muscles in experimental tank to those of control tank on specific days of sampling. The bioaccumulation profiles for copper and zinc show a steady increase of heavy metal concentrations inside fish muscles with respect to time until the concentrations reach to a plateau. The increasing trend of accumulation can be well understood by the $R^{2}$ value of 0.897 and 0.896 for $\mathrm{Cu}$ and $\mathrm{Zn}$ respectively. In addition, the trends of accumulation are statistically significant $(P<0.05)$ for both $\mathrm{Cu}$ and $\mathrm{Zn}$. From the graph, the accumulation rate of $\mathrm{Zn}$ in fish muscle can be subdivided into two phases; the first phase until day 7 (19.63 ppm) shows the highest accumulation rate, while the trend gets lower from day 7 to 15 . In the meantime, the $\mathrm{Cu}$ concentration seems to increase until day $9(4.10 \mathrm{ppm})$ and later shows little increment from day 9 to 15 . Hence, it is evident that the major uptake of $\mathrm{Cu}$ and $\mathrm{Zn}$ occurs within 7 to 9 days. Although the qualitative trends for $\mathrm{Cu}$ and $\mathrm{Zn}$ seem more or less similar, however, $\mathrm{Zn}$ is accumulated at a much higher rate than $\mathrm{Cu}$ in fish muscle. The highest accumulation for $\mathrm{Zn}$ is observed at $25.97 \mathrm{ppm}$ for the fish species at day 15; whereas highest accumulation for $\mathrm{Cu}$ is observed at $4.63 \mathrm{ppm}$ for identical set up. Similar outcome has been reported by previous studies (Alkan, Alkan, Gedik, \& Fisher, 2016; Begum et al., 2013; Cui et al., 2015; Orata \& Birgen, 2016) which observed higher level of accumulation of $\mathrm{Zn}$ than the $\mathrm{Cu}$ in fish muscles for different fish species. The present laboratory observation remains significantly lesser than the previously reported uptake rates of $\mathrm{Cu}$ and $\mathrm{Zn}$ (Rahman et al., 2012; Ahmed et al., 2015) from the field level data of fish species in Bangladesh. However, one previous study by Begum et al., (2013) on shingi fish (Heteropneustes fossilis) from Buriganga river reported somewhat similar order of concentrations which ranged between $7.80-8.50 \mathrm{mg} / \mathrm{kg}$ for $\mathrm{Cu}$ and 24.47 to 28.82 $\mathrm{mg} / \mathrm{kg}$ for $\mathrm{Zn}$. It is important to note that, both the species (Heteropneustes fossilis in previous study and Anabas testudineus in current study) are known for their high susceptibility among the local fish species. Hence, similar order of accumulation rates might have been obtained due to their similar physical attributes. Though the previous study dealt with field level observation only, however, the comparison enabled understanding the difference between field level observation and data from experimental setup. Further investigation is required with metal exposure at different levels to relate with field level observation.

$\mathrm{Zn}$ and $\mathrm{Cu}$ are constituents of enzymes and haemocyanin, indispensable for the proper functioning of metabolic processes. However, mechanism of 


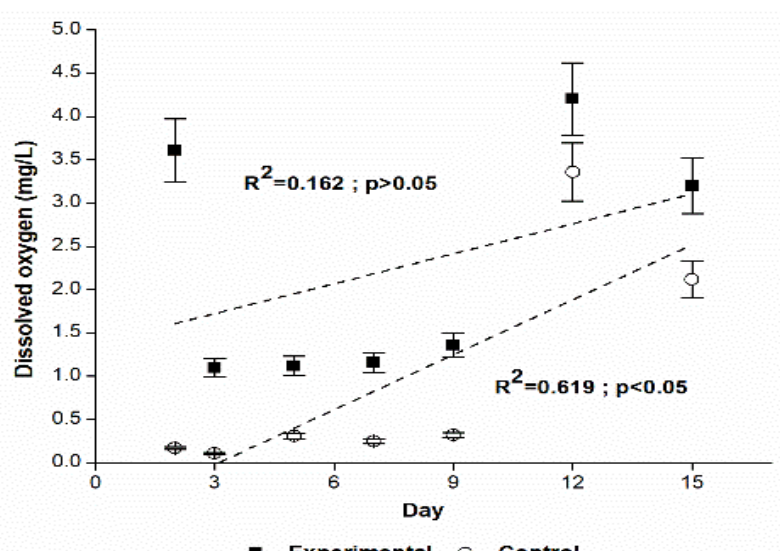

(a)

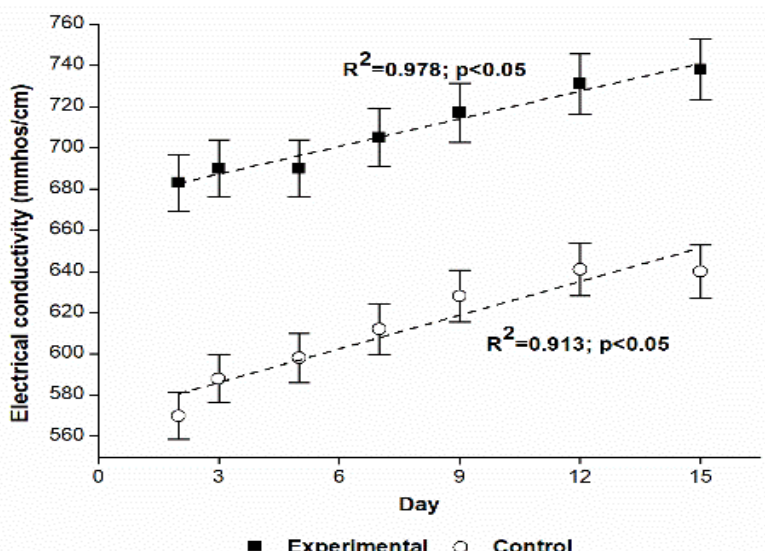

(c)

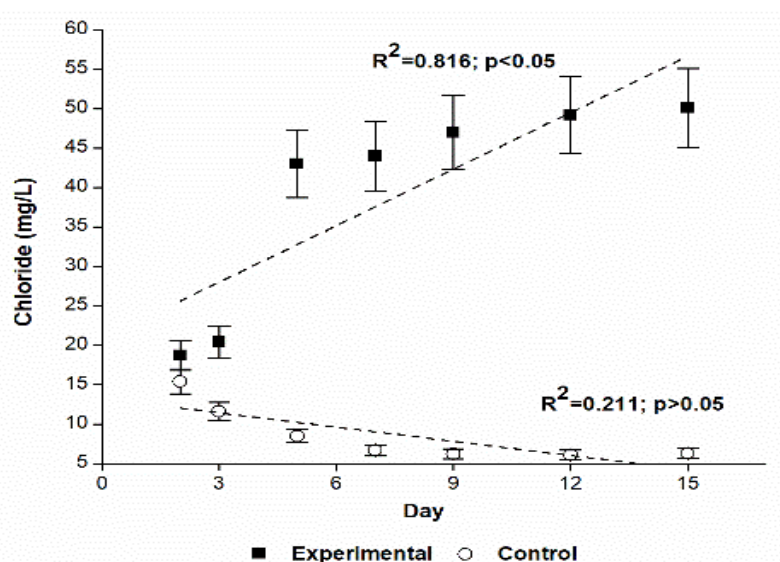

(b)

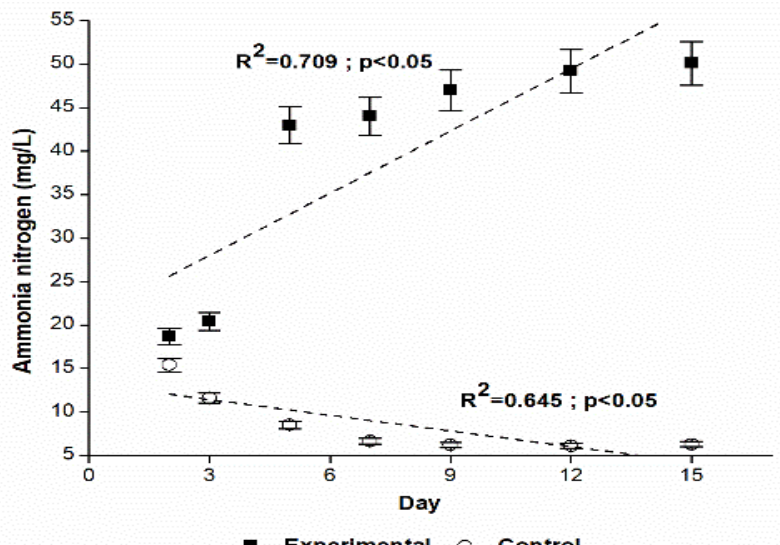

(d)

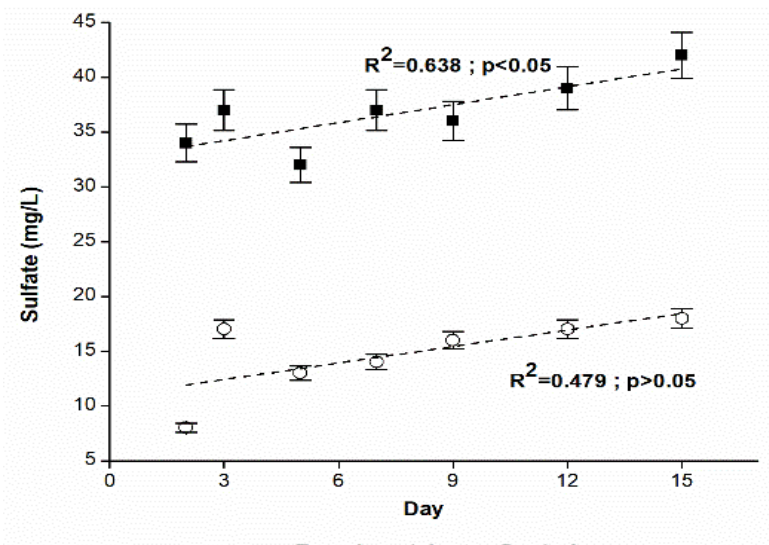

- Experimental O Control

(e)

Figure 2. Water quality parameters in experimental tank as a function of time: (a) Dissolved oxygen; (b) Chloride; (c) Electrical conductivity; (d) Ammonia- nitrogen and (e) Sulfate. 


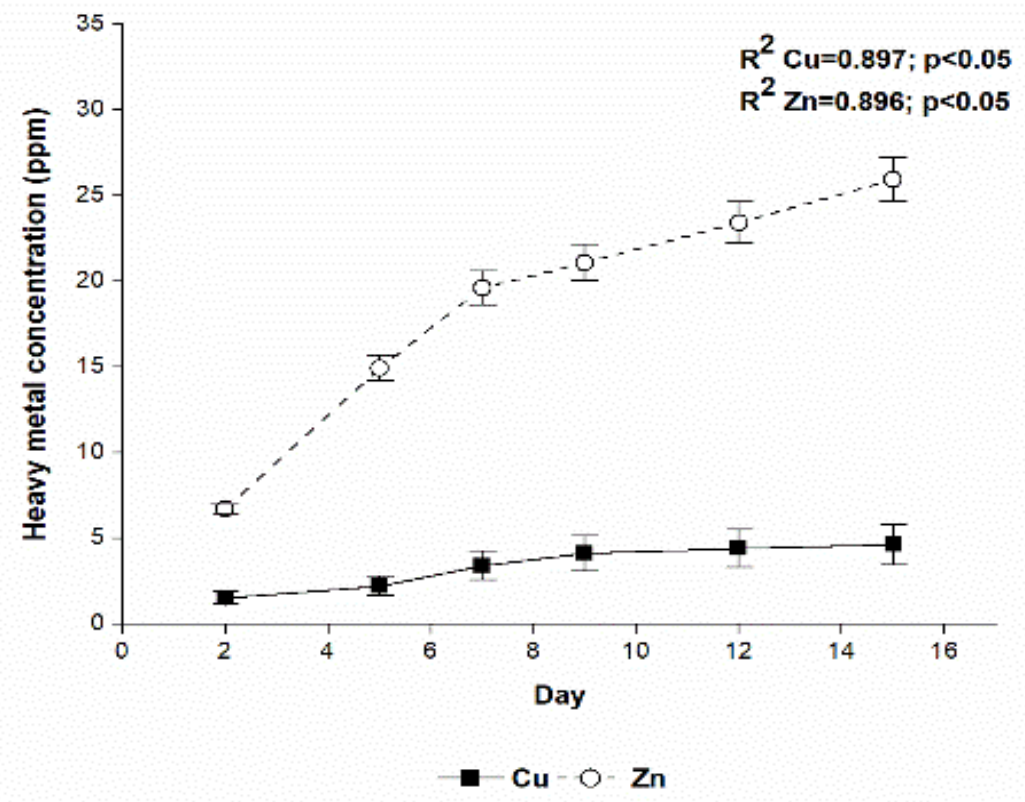

Figure 3. Variation of $\mathrm{Cu}$ and $\mathrm{Zn}$ concentration in fish muscles as a function of time.

qualitative and quantitative bioaccumulation of copper and zinc metals in fish muscle is less understood. Present study focuses on the bio-concentration factor or $\mathrm{BCF}$ to understand the accumulation pattern with days which is provided in later section.

Figure 4 shows the concentration trends of $\mathrm{Cu}$ and $\mathrm{Zn}$ in the water of experimental tank where the metal salts were dosed. Metal concentrations in water shows decreasing trend in general with the passage of time ( 15 days) until those reached a steady value (Figure 4). With time, the concentration of $\mathrm{Cu}$ is found to decrease with $R^{2}$ value of 0.578 whereas the concentration trend of $\mathrm{Zn}\left(\mathrm{R}^{2}=0.08\right)$ in water is observed to remain almost stable. The decreasing trend of $\mathrm{Cu}$ does not deviate from the expectation that uptake of metals inside fish muscles should be concomitant with the reduction of the same in water. However, previous studies also observed that fish is able to accelerate $\mathrm{Cu}$ depuration from the body by excreting $\mathrm{Cu}$ to the external environment when $\mathrm{Cu}$ accumulation exceeds a critical level (Tsai et al., 2013). Hence the decrease of Cu level in water is not in complete numeric agreement with the incremental trend in fish muscles. The insignificant $R^{2}$ value for $\mathrm{Zn}$ in water suggests that the concentration of $Z n$ remains much less affected by the accumulation of $\mathrm{Zn}$ from water into fish muscle. Furthermore, Zn concentration in fish feces also might be the reason of increase in $\mathrm{Zn}$ concentration in the water, which has made the concentration almost stable despite being highly accumulated in the fish muscle. Previous studies have reported significant zinc excretion through the fish feces as well (Geeseyl, Alexander, Brag, \& Miles, 1984; Hardy, Sullivan, \& Koziol, 1987).

\section{Dynamic Variation in Water Quality Parameters on Metal Dosing and Fish Metabolism}

Pearson correlation coefficient matrix has been prepared as shown in Tables 1 and 2 among the water quality parameters and heavy metals in control and experimental tanks respectively during the experimental duration. Previously, Ahmad et al., (2010) had performed correlation analysis between heavy metal parameters in the river water, sediment and fish muscle, whereas Cui et al., (2015) explored the correlation of heavy metals in fish and sediment of a lake in china. However, the present study attempted to investigate the correlation among the parameters for both control and experimental conditions to understand the dynamics after addition of metal species in the tanks by comparing the correlation indices between the experimental and the control tanks. The correlations that are significant have been denoted in bold number.

In general, dissolved oxygen seems to be negatively correlated with other quality parameters in both the tanks but positively correlated with chloride. In general, negative correlation (larger than 0.622) is observed between ammonia-nitrogen and dissolved oxygen in both the tanks. The nitrogen from fish feces is possibly responsible for decreasing of oxygen level to decompose these organic matters. Significant negative correlation $(\mathrm{P}<0.05)$ is found for chloride with $\mathrm{pH}, \mathrm{EC}$, TDS and alkalinity in the control tank while the correlations are positive for these parameters with chloride in the experimental tank.

In comparison with the control tank, correlation co-efficient of sulfate with rest of the water quality parameters seem to increase in the experimental tank. 


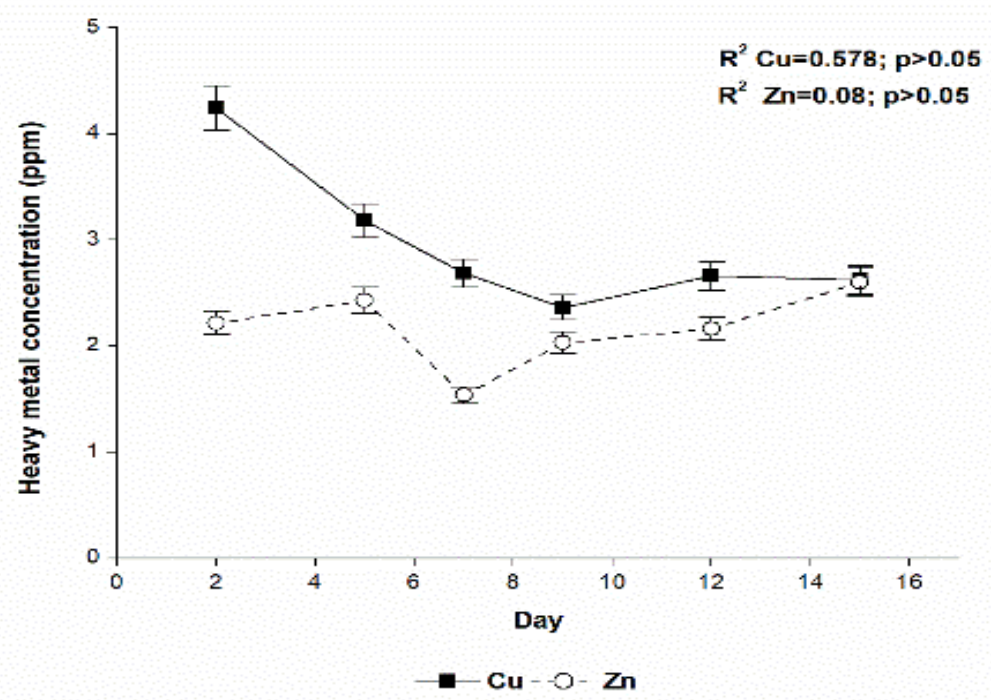

Figure. 4 Variation of $\mathrm{Cu}$ and $\mathrm{Zn}$ concentration in water of as a function of time.

Table 1. Pearson correlation co-efficient between observed water quality parameters in control tank

\begin{tabular}{|c|c|c|c|c|c|c|c|c|c|c|c|}
\hline & $\mathrm{EC}$ & A.nitrogen & Chloride & Sulfate & $\mathrm{pH}$ & TDS & DO & Alkalinity & T. Hardness & $\mathrm{Cu}$ & $\mathrm{Zn}$ \\
\hline EC & 1 & & & & & & & & & & \\
\hline A. nitrogen & 0.454 & 1 & & & & & & & & & \\
\hline Chloride & $-0.945^{*}$ & -0.655 & 1 & & & & & & & & \\
\hline Sulfate & 0.805 & -0.155 & -0.596 & 1 & & & & & & & \\
\hline $\mathrm{pH}$ & $0.921^{*}$ & 0.306 & $-0.914^{*}$ & 0.790 & 1 & & & & & & \\
\hline TDS & $0.999^{*}$ & 0.420 & $-0.936^{*}$ & $0.825 *$ & $0.927^{*}$ & 1 & & & & & \\
\hline DO & -0.598 & -0.707 & 0.806 & -0.153 & -0.684 & -0.582 & 1 & & & & \\
\hline Alkalinity & $0.923 *$ & 0.596 & $-0.941 *$ & 0.639 & $0.879 *$ & $0.915^{*}$ & -0.692 & 1 & & & \\
\hline T. Hardness & 0.041 & 0.416 & -0.164 & -0.260 & -0.050 & 0.022 & -0.499 & -0.046 & 1 & & \\
\hline $\mathrm{Cu}$ & 0.124 & $0.852^{*}$ & -0.382 & -0.418 & 0.096 & 0.093 & -0.545 & 0.416 & 0.87 & 1 & \\
\hline $\mathrm{Zn}$ & -0.433 & 0.317 & 0.142 & -0.734 & -0.252 & -0.447 & -0.230 & -0.229 & 0.001 & 0.647 & 1 \\
\hline
\end{tabular}

*significantly correlated at 0.05 level (2tailed)

Table 2. Pearson correlation co-efficient between observed water quality parameters in experimental tank

\begin{tabular}{|c|c|c|c|c|c|c|c|c|c|c|c|}
\hline & EC & A.nitrogen & Chloride & Sulfate & $\mathrm{pH}$ & TDS & DO & Alkalinity & T. Hardness & $\mathrm{Cu}$ & $Z n$ \\
\hline EC & 1 & & & & & & & & & & \\
\hline A.nitrogen & $0.884 *$ & 1 & & & & & & & & & \\
\hline Chloride & 0.105 & 0.410 & 1 & & & & & & & & \\
\hline Sulfate & $0.994 *$ & $0.865^{*}$ & 0.077 & 1 & & & & & & & \\
\hline pH & 0.873* & $0.955^{*}$ & 0.556 & 0.843* & 1 & & & & & & \\
\hline TDS & $1.0 *$ & $0.885^{*}$ & 0.108 & $0.994 *$ & $0.875^{*}$ & 1 & & & & & \\
\hline DO & -0.525 & -0.622 & 0.191 & -0.476 & -0.453 & -0.526 & 1 & & & & \\
\hline Alkalinity & $0.981^{*}$ & $0.874 *$ & 0.189 & $0.990^{*}$ & $0.876^{*}$ & $0.981 *$ & -0.383 & 1 & & & \\
\hline T. hardness & 0.732 & 0.328 & -0.414 & 0.748 & 0.361 & 0.730 & -0.173 & 0.708 & 1 & & \\
\hline $\mathrm{Cu}$ & 0.796 & 0.451 & -0.272 & 0.788 & 0.505 & 0.796 & -0.324 & 0.737 & $0.941 *$ & 1 & \\
\hline $\mathrm{Zn}$ & 0.733 & 0.556 & 0.242 & 0.675 & 0.725 & 0.734 & -0.270 & 0.679 & 0.642 & 0.795 & 1 \\
\hline
\end{tabular}

*significantly correlated at 0.05 level (2tailed) 
Sulfate is found to be positively correlated $(P<0.05)$ with $\mathrm{pH}, \mathrm{TDS}, \mathrm{EC}$, alkalinity and ammonia-nitrogen in the experimental tank. This might have been caused due to the elevated level of sulfate ion with introduction of sub lethal metal salt solution. Meanwhile, in control tank sulfate is found to be significantly correlated with TDS only.

Relatively weak correlation can be observed between the heavy metals ( $\mathrm{Cu}$ and $\mathrm{Zn}$ ) and the other water quality parameters in the control tank since tap water was used in the control tank without dosing. However, the correlation coefficients exhibited notable changes in the experimental tank due to the addition of the metal solutions and metabolism in fish species. Both $\mathrm{Cu}$ and $\mathrm{Zn}$ exhibits a positive correlation $\left(R^{2}>0.675\right)$ with EC, TDS, total hardness, alkalinity and sulfate in the experimental tank. This correlation clearly indicates the impact of addition of metal salts in increasing the sulfate and $\mathrm{pH}$, which eventually increases the concentration of EC and TDS. Again, decreased negative correlation of heavy metals with DO in the experimental tank than the control tank suggests that the high concentration of heavy metals influenced the DO level to increase in the experimental tank because of decreased metabolism in fishes. Furthermore, concentrations of $\mathrm{Cu}$ are observed to have stronger correlation with EC (0.796), sulfate (0.788), TDS (0.734) alkalinity (0.73) and total hardness (0.941) than with the concentrations of $\mathrm{Zn}$. It indicates that the dosing of mainly Cu exerts certain impact on the dynamics of water quality parameters of the experimental tank with sub-lethal metal solution. Previous field level studies (Gupta, Rai, Pandey \& Sharma, 2009; Dhanakumar, Solaraj, \& Mohanraj, 2015) have reported the accumulation of heavy metals mainly from sediments rather than from aquatic compartment itself for some species. However, batch scale study with only water as the only source of metal such as the present one enabled us to identify that fishes can positively accumulate metals from water inside muscles while altering the water quality parameters' dynamics alongside which provides insights into the changing chemistry in the aquatic habitats. Investigation on sediment enriched aquatic system in controlled condition might exhibit different dynamics with the fish species.

\section{Analysis of Bio-concentration Factors of Metals in Anabas testudineus}

Bioconcentration factor is the result of the uptake, distribution and elimination of chemicals after the direct exposure of the organism to a polluted matrix (Sikdar \& Kundu, 2018). Previous studies (Cui et al., 2015; Dwivedi et al., 2015) measured BCF of heavy metals in fish species from natural water bodies, whereas some others (Falusi \& Olanipekun, 2007; Orata \& Birgen, 2016) studied the BCF of heavy metals in crabs. However, no significant study has been found to measure BCF at laboratory settings in controlled experimental condition for specific duration. This study attempts to assess the trends of BCF of $\mathrm{Cu}$ and $\mathrm{Zn}$ in laboratory setup with days. Figures 5 and 6 show the trends of the bioconcentration factors for $\mathrm{Cu}$ and $\mathrm{Zn}$, which indicate the variation of the factor with days. Table 3 provides the values of Pearson correlation coefficient and regression factor between the values of $\mathrm{BCF}$ and the concentration levels of heavy metals in fish muscle and water in the experimental tank.

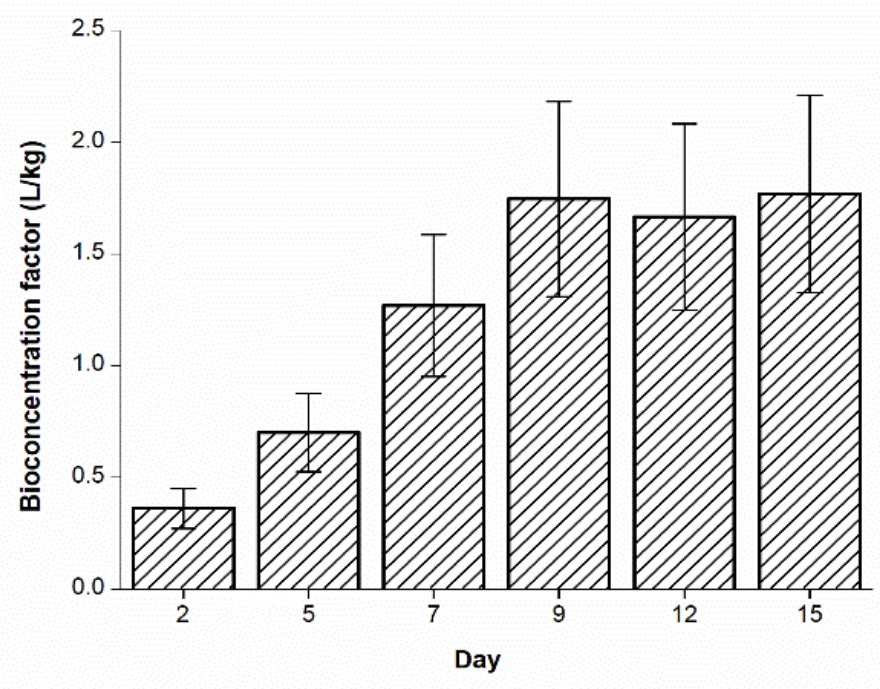

Figure. 5 Bioconcentration factor of $\mathrm{Cu}$ in fish muscle as a function of time. 


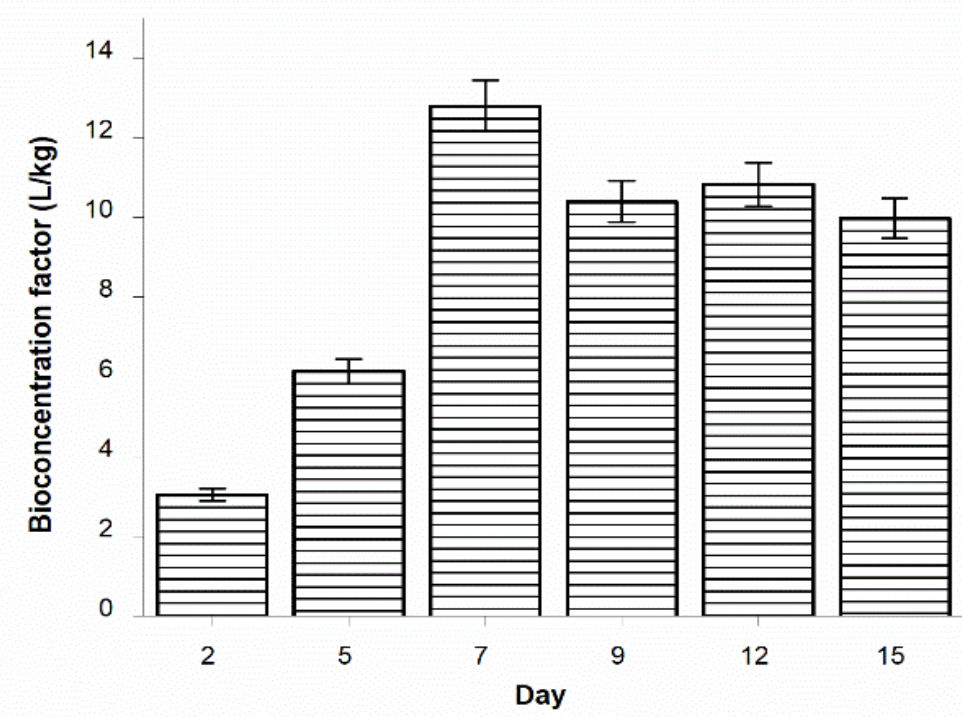

Figure. 6 Bioconcentration factor of $\mathrm{Zn}$ in fish muscle as a function of time.

Table 3. Pearson correlation coefficient and regression values between BCF values to concentrations of metals in fish muscles and water in experimental tank

\begin{tabular}{|c|c|c|c|c|}
\hline & Fish muscles & & & \\
\hline & Pearson coefficient & $\mathbf{R}^{\mathbf{2}}$ & Pearson coefficient & $\mathbf{R}^{\mathbf{2}}$ \\
\hline BCF (Zn) & $0.845 *$ & 0.71 & -0.486 & 0.24 \\
\hline $\mathrm{BCF}(\mathrm{Cu})$ & $0.823 *$ & 0.98 & $-0.901 *$ & 0.84 \\
\hline
\end{tabular}

*significant at 0.05 level

The increasing trend of bioconcentration factor of $\mathrm{Cu}$ in the fish is evident from figure 5 . The highest value of the factor $(1.77 \mathrm{~L} / \mathrm{kg}$ ) was recorded at day 15 . In brief, it could be said that the BCF value increases until the $9^{\text {th }}$ day $\left(0.36^{\sim} 1.74 \mathrm{~L} / \mathrm{kg}\right)$, while in later days until day $15, \mathrm{BCF}$ values exhibit more steady values of bioconcentration factor in the fish for $\mathrm{Cu}$. The Pearson correlation coefficient indicates that BCF is positively correlated with $\mathrm{Cu}$ concentration in fish muscle and negatively correlated with the concentration of $\mathrm{Cu}$ in water (Table 3). However, both the correlations are observed to be statistically significant at 0.05 level. Moreover, strong regression is obtained for $\mathrm{BCF}$ of $\mathrm{Cu}$ with both the concentration of $\mathrm{Cu}$ in Fish muscle $(98 \%)$ and that in the water (84\%).

Bioconcentration factor of $\mathrm{Zn}$ also shows significant increase $(3.04 \sim 12.79 \mathrm{~L} / \mathrm{kg}$ ) until day 7 (Figure. 6). Being much higher than that for $\mathrm{Cu}$, the values of $\mathrm{BCF}$ for $\mathrm{Zn}$ decreases from the value of day 7 and becomes stable from day 9 onwards similar to those for $\mathrm{Cu}$. Although the highest concentration of $\mathrm{Zn}$ in fish muscle was observed (25.97 ppm) at day 15 but the bioconcentration factor is observed to lower down after $7^{\text {th }}$ day and reach $<10 \mathrm{~L} / \mathrm{kg}$ on $15^{\text {th }}$ day. The reason can be well explained by the correlation of BCF to concentration of $\mathrm{Zn}$ in fish muscle and water (Table 3 ). The BCF is significantly and positively $(P<0.05)$ correlated with concentration of $\mathrm{Zn}$ in fish muscle but negatively correlated with the concentration in water. The negative correlation $(-0.486)$ between $\mathrm{Zn}$ concentration in water and BCF of Zn cannot be deemed as significant as was obtained for $\mathrm{Cu}(-0.9)$. More specifically, the stable concentration of $\mathrm{Zn}$ in water tank has caused lowest BCF at day 15 though the concentration of $\mathrm{Zn}$ has been highest in fish muscle at the same day. It is interesting to note from figure 2 that the rate of $\mathrm{Zn}$ uptake in fish muscle decreases from day 7 ie the slope of the line becomes flatter whereas the BCF value also decreases onwards beyond day 7 concomitantly. It should be noted that a previous study by DeForest et al., (2007) has also found inverse relationship between Bio-concentration factor and the concentration of $\mathrm{Zn}$ in water. To sum up, an increasing trend can be observed for BCF values for both of the metals in initial days while the values becoming stable or constant eventually. BCF values of $\mathrm{Zn}$ were mostly 5- 
10 times higher than those of the values of $\mathrm{Cu}$. It is also important to mention that highest BCF of $\mathrm{Zn}$ was obtained in previous studies as well by Falusi and Olanipekun (2007) compared to $\mathrm{Cu}$ in crab muscles, but this was not essentially true from the findings by some other studies (Dwivedi et al., 2015; Orata \& Birgen, 2016) for different fish species. However, all of these studies consisted of sampling directly from natural water bodies. No significant study reported BCF in experimental set-up for continued duration.

\section{Conclusion}

This study attempted to evaluate the uptake phenomenon of $\mathrm{Cu}$ and $\mathrm{Zn}$ metals in the commonly found fish species in Bangladesh, Anabas testudeneous in controlled laboratory environment for a specific duration. Apart from the metal uptake pattern inside the fish muscles upon metal dosing, trends of different physio-chemical water quality parameters and the selected heavy metals over the experimental duration and internal correlation among the parameters were also studied in both control and experimental conditions. With the same concentrations of metal dosing, uptake of $\mathrm{Zn}$ in fish occurred at an elevated level ( 7-8 times) than that of $\mathrm{Cu}$. With continuous uptake of metals in fish muscles from water, $\mathrm{Cu}$ concentration in the water decreased concomitantly whereas the concentration of $\mathrm{Zn}$ did not change suggesting the balancing of $\mathrm{Zn}$ level from other source such as excretion from Fish. Correlation analysis indicated significant changes in internal dynamics such as, correlation between chloride and the parameters $\mathrm{pH}, \mathrm{EC}$, TDS and alkalinity changed from positive to negative in control to experimental tank respectively. Both of the metals exhibited positive correlation with EC, TDS, total hardness, alkalinity and sulfate in the experimental tank, however the correlations were stronger with $\mathrm{Cu}$ than with $\mathrm{Zn}$. Bio-concentration profile for both the metals revealed very high levels for $\mathrm{Zn}$ (5-10 times) than for $\mathrm{Cu}$ evidently due to higher amount of uptake of $\mathrm{Zn}$ than $\mathrm{Cu}$ inside fish muscles. Correlation and regression coefficients indicated that impact of respective metal concentration in the surrounding has much stronger impact on the bio-concentration factor for $\mathrm{Cu}$ than on the bio-concentration factor for $\mathrm{Zn}$. These results indicate that the dynamics of heavy metal metabolism in the fish species and their respective correlation with the water quality parameters may not be same for all the heavy metals and even for different fish species.

\section{References}

Ahmad, M.K., Islam, S., Rahman, M.S., Haque, M.R., \& Islam, M.M. (2010). Heavy Metals in Water, Sediment and Some Fishes of Buriganga River, Bangladesh. International Journal of Environmental Resarch, 4(2), 321-332.
Ahmed, M.K., Baki, M.A., Islam, M. S., Kundu, G.K., HabibullahAl-Mamun, M., Sarkar, S.K., \& Hossain, M.M. (2015). Human health risk assessment of heavy metals in tropical fish and shellfish collected from the river Buriganga, Bangladesh. Environmental Science and Pollution Research, 22(20), 15880-15890. https://doi.org/10.1007/s11356-015-4813-z

Alkan, N., Alkan, A., Gedik, K., \& Fisher, A. (2016). Assessment of metal concentrations in commercially important fish species in Black Sea. Toxicology and Industrial Health, 32(3), 447-456.

https://doi.org/10.1177/0748233713502840

Ambreen, F., Javed, M., \& Batool, U. (2015). Tissue specific heavy metals uptake in economically important Fish, Cyprinus carpio at acute exposure of metals mixtures. Pakistan Journal of Zoology, 47(2), 399-407.

Amiard, J.C., Amiard-Triquet, C., Berthet, B., \& Metayer, C. (1987). Comparative study of the patterns of bioaccumulation of essential $(\mathrm{Cu}, \mathrm{Zn})$ and non-essential $(\mathrm{Cd}, \mathrm{Pb})$ trace metals in various estuarine and coastal organisms. Journal of Experimental Marine Biology and Ecology, 106(1), 73-89. https://doi.org/10.1016/00220981(87)90148-1

Begum, A., Mustafa, A.I., Amin, M.N., Chowdhury, T.R., Quraishi, S.B., \& Banu, N. (2013). Levels of heavy metals in tissues of shingi fish (Heteropneustes fossilis) from Buriganga River, Bangladesh. Environmental Monitoring and Assessment, 185(7), 5461-5469. https://doi.org/10.1007/s10661-012-2959-4

Bhaskar, P., Pyne, S.K., \& Ray, A.K. (2015). Growth performance study of Koi fish, Anabas testudineus (Bloch) by utilization of poultry viscera, as a potential fish feed ingredient, replacing fishmeal. International Journal of Recycling of Organic Waste in Agriculture, 4(1), 31-37.

Boudjema, K., Meknachi, A., Kourdali, S., Bounakous, N., \& Badis, A. (2016). Effect of sublethal concentrations of heavy metals (cadmium, lead, and copper) on the soluble nitrogen and phosphorus excretion of marine brown mussel (Perna perna) (Linnaeus, 1758) (Mollusca; Bivalvia) Kamel. International Journal of Fisheries and Aquatic Studies, 4(2), 455-462.

Bouquegnean, J.M., Noel-Lambot, F., \& Disteche, A. (1979). Fate of heavy metals in experimental aquatic food chains. Uptake and release of $\mathrm{Hg}$ and $\mathrm{Cd}$ by some marine organisms. Role of metallothioneins. Int. Counc. Explor. Sea Comm. Meet. (Mar. envirl Qual. Comm.), 58, 85-122.

Bradl, H. (2005). Heavy metals in the environment: origin, interaction and remediation (Eds.), Interface Science and Technology (Vol.6), Elsevier Academic Press.

Chandurvelan, R., Marsden, I.D., Glover, C.N., \& Gaw, S. (2015). Assessment of a mussel as a metal bioindicator of coastal contamination: Relationships between metal bioaccumulation and multiple biomarker responses. Science of the Total Environment, 511, 663-675. https://doi.org/10.1016/j.scitotenv.2014.12.064

Cheung, S.G., \& Cheung, R.Y.H. (1995). Effects of heavy metals on oxygen consumption and ammonia excretion in green-lipped mussels (Perna viridis). Marine Pollution Bulletin, 31(4-12), 381-386. https://doi.org/10.1016/0025-326X(95)00137-C

Clesceri, L.S., Greenbaerg, A.E., \& Eaton, A.D. (1998). Standard Methods for Examination of Water and Wastewater (Standard Methods for the Examination of Water and Wastewater). American Public Health Association (APHA), Washington DC, USA., 1325 pp. 
Cui, L., Ge, J., Zhu, Y., Yang, Y., \& Wang, J. (2015) Concentrations, bioaccumulation, and human health risk assessment of organochlorine pesticides and heavy metals in edible fish from Wuhan, China. Environmental Science and Pollution Research, 22(20), 15866-15879. https://doi.org/10.1007/s11356-015-4752-8

DeForest, D.K., Brix, K.V., \& Adams, W.J. (2007). Assessing metal bioaccumulation in aquatic environments: The inverse relationship between bioaccumulation factors, trophic transfer factors and exposure concentration. Aquatic Toxicology, 84(2), 236-246.

https://doi.org/10.1016/j.aquatox.2007.02.022

De Montaudouin, X., Paul-Pont, I., Lambert, C., Gonzalez, P., Raymond, N., Jude, F., ... \& Le Goïc, N. (2010). Bivalve population health: multistress to identify hot spots. Marine pollution bulletin, 60(8), 1307-1318. https://doi.org/10.1016/j.marpolbul.2010.03.011

Dhanakumar, S., Solaraj, G., \& Mohanraj, R. (2015). Heavy metal partitioning in sediments and bioaccumulation in commercial fish species of three major reservoirs of river Cauvery delta region, India. Ecotoxicology and Environmental Safety, 113, 145-151.

Dwivedi, A.C., Tiwari, A., \& Mayank, P. (2015). Seasonal determination of heavy metals in muscle, gill and liver tissues of Nile tilapia, Oreochromis niloticus (Linnaeus, 1758) from the tributary of the Ganga River, India. Zoology and Ecology, 25(2), 166-171. https://doi.org/10.1080/21658005.2015.1020012

Falusi, B.A., \& Olanipekun, E.O. (2007). Bioconcentration factors of heavy metals in tropical crab (Carcinus sp.) from River. Journal of Applied Science, Environment and Management, 11(4), 51-54.

Geesey, G.G., Alexander, G.V., Bray, R.N., \& Miller, A.C. (1984). Fish fecal pellets are a source of minerals for inshore reef communities. Marine ecology progress series. Oldendorf, 15(1), 19-25.

Gobas, F.A.P.C., \& Morrison, H.A., (2000). Bioconcentration and biomagnification in the aquatic environment, in: Boethling, R.S., Mackay, D. (Eds.), Handbook of Property Estimation Methods for Chemicals, Lewis Publishers, Boca Raton, FL, 189-231 pp.

Gupta, A., Rai, D.K., Pandey, R.S., \& Sharma, B. (2009). Analysis of some heavy metals in the riverine water, sediments and fish from river Ganges at Allahabad. Environmental Monitoring and Assessment, 157(1-4), 449-458. https://doi.org/10.1007/s10661-008-0547-4

Hardy, R.W., Sullivan, C.V, \& Koziol, A.M. (1987). Absorption, body distribution, and excretion of dietary zinc by rainbow trout (Salmo gairdneri). Fish Physiology and Biochemistry, 3(3), 133-134.

https://doi.org/10.1007/BF02180415

Hogstrand, C., Wilson, R.W., Polgar, D., \& Wood, C.M. (1994). Effects of zinc on the kinetics of branchial calcium uptake in freshwater rainbow trout during adaptation to waterborne zinc. Journal of Experimental Biology, 186(1), 55-73.

Hughes, G.M., \& Singh, B.N. (1970). Respiration in an AirBreathing Fish, the Climbing Perch, Anabas Testudineus: II. Respiratory Patterns and the Control of Breathing. Journal of Experimental Biology, 53(2), 281-298.

Islam, M.S., Ahmed, M.K., Raknuzzaman, M., Habibullah-AlMamun, M., \& Islam, M.K. (2015). Heavy metal pollution in surface water and sediment: a preliminary assessment of an urban river in a developing country. Ecological indicators, 48, 282-291.
Mohiuddin, K.M., Ogawa, Y., Zakir, H.M., Otomo, K., \& Shikazono, N. (2011). Heavy metals contamination in water and sediments of polluted urban rivers in developing countries. International Journal of Environmental Science and Technology, 8(4), 723-736. https://doi.org/10.1007/BF03326257

Mohiuddin, K.M., Otomo, K., Ogawa, Y., \& Shikazono, N. (2012). Seasonal and spatial distribution of trace elements in the water and sediments of the Tsurumi River in Japan. Environmental Monitoring and Assessment, 184(1), 265-279.

Murugan, S., Karuppasamy, R., \& Poongodi, K. (2008). Bioaccumulation Pattern of Zinc in Freshwater Fish Channa punctatus(Bloch.) After Chronic Exposure. Turkish Journal of Fisheries and Aquatic Sciences, 8(1), 55-59.

Orata, F., \& Birgen, F. (2016). Fish Tissue Bio-concentration and Interspecies Uptake of Heavy Metals from Waste Water Lagoons. Journal of Pollution Effects \& Control, 04(02). https://doi.org/10.4172/2375-4397.1000157

Pan, K., \& Wang, W.X. (2012). Trace metal contamination in estuarine and coastal environments in China. Science of The Total Environment, 421, 3-16.

Rahman, M.S., Molla, A.H., Saha, N., \& Rahman, A. (2012). Study on heavy metals levels and its risk assessment in some edible fishes from Bangshi River, Savar, Dhaka, Bangladesh. Food Chemistry, 134(4), 1847-1854. https://doi.org/10.1016/j.foodchem.2012.03.099

Sarkar, M., Rahman, A.L., Islam, J.B., Ahmed, K.S., Uddin, M. N., \& Bhoumik, N.C. (2015). Study of hydrochemistry and pollution status of the Buriganga river, Bangladesh. Bangladesh Journal of Scientific and Industrial Research, 50(2), 123-134.

https://doi.org/10.3329/bjsir.v50i2.24353

Sarma, K., Pal, A.K., Ayyappan, S., Das, T., Manush, S.M., Debnath, D., \& Baruah, K. (2010). Acclimation of Anabas testudineus (Bloch) to three test temperatures influences thermal tolerance and oxygen consumption. Fish physiology and biochemistry, 36(1), 85-90.

Sikdar, S., \& Kundu, M. (2018). A Review on Detection and Abatement of Heavy Metals. ChemBioEng Reviews, 5(1), 18-29. https://doi.org/10.1002/cben.201700005

Shukla, V., Dhankhar, M., Prakash, J., \& Sastry, K.V. (2007). Bioaccumulation of $\mathrm{Zn}, \mathrm{Cu}$ and $\mathrm{cd}$ in Channa punctatus. Journal of Environmental Biology, 28(2), 395-397.

Tsai, J.W., Ju, Y.R., Huang, Y.H., Deng, Y.S., Chen, W.Y., Wu, C.C., \& Liao, C.M. (2013). Toxicokinetics of tilapia following high exposure to waterborne and dietary copper and implications for coping mechanisms. Environmental Science and Pollution Research, 20(6), 3771-3780. https://doi.org/10.1007/s11356-012-13043

Tsangaris, C., Kormas, K., Strogyloudi, E., Hatzianestis, I., Neofitou, C., Andral, B., \& Galgani, F. (2010). Multiple biomarkers of pollution effects in caged mussels on the Greek coastline. Comparative Biochemistry and Physiology Part C: Toxicology \& Pharmacology, 151(3), 369-378.

Vieira, C., Morais, S., Ramos, S., Delerue-Matos, C., \& Oliveira, M.B.P.P. (2011). Mercury, cadmium, lead and arsenic levels in three pelagic fish species from the Atlantic Ocean: Intra- and inter-specific variability and human health risks for consumption. Food and Chemical Toxicology, 49(4), 923-932. https://doi.org/10.1016/j.fct.2010.12.016 
Vinodhini, R., \& Narayanan, M. (2008). Bioaccumulation of heavy metals in organs of fresh water fish Cyprinus carpio (Common carp). International Journal of Environmental Science and Technology, 5(2), 179-182. https://doi.org/10.1007/BF03326011

Yılmaz, A.B., Turan, C., \& Toker, T. (2010). Uptake and distribution of hexavalent chromium in tissues (gill, skin and muscle) of a freshwater fish, Tilapia, Oreochromis aureus. Journal of Environmental Chemistry and Ecotoxicology, 2(3), 28-33

Zazouli, M.A., Yousefi, Z., Taghavi, M., Akbari-adergani, B., \& Yazdani Cherati, J. (2013). Removing Cadmium from Aqueous Environments using L-cysteine Functionalized Single-Walled Carbon Nanotubes. Journal of Mazandaran University of Medical Sciences, 23(98), 3747. 